\title{
Implicature in Architecture
}

\author{
Bambang Sumadyo $^{1}$, Yulia Agustin ${ }^{2}$, Rr. Astri Indriana Octavita ${ }^{3}$, Bambang Perkasa Alam ${ }^{4}$ \\ \{bambang0910@gmail.com ${ }^{1}$, yuliaagustin.unindra@gmail.com ${ }^{2}$, mrs.astriindriana@ gmail.com ${ }^{3}$, \\ perkasaalam.bambang@gmail.com $\left.{ }^{4}\right\}$ \\ Universitas Indraprasta PGRI, Jakarta, Indonesia ${ }^{1234}$
}

\begin{abstract}
As a communication tool, the use of good language must consider the context. The relationship between language, implicature, and discourse of housing advertising can be said to be very close. The need of language sector for housing advertising was increasingly important because of the existence of an object (housing) that must be published or marketed. The use of monotonous and straightforward language will give the impression of being unattractive and unworthy of sale. Conversely, the use of language that is conditioned to create an impression of luxury will attract buyers. This study aims to determine how language was used to create a good, luxury, and high selling impression in housing advertisements. The approach used was a qualitative approach, with data collection conducted by observation and taking notes. Research data in the form of housing advertising brochures were collected for one month. The results showed that language is a very important factor in commercial communication. Plain and simple language will have casual repercussions. However, the conditioned language will give the impression of being modern, luxurious, of quality, and extraordinary.
\end{abstract}

Keywords: implicature, discourse, advertisement, housing

\section{Implikatur dalam Dunia Arsitektur}

\begin{abstract}
Abstrak. Sebagai alat komunikasi, penggunaan bahasa yang baik harus mempertimbangkan konteks. Keterkaitan antara bahasa, implikatur, dan wacana iklan perumahan dapat dikatakan sangat erat. Kebutuhan iklan perumahan akan bidang bahasa semakin penting karena adanya sebuah objek (rumah) yang harus dipublikasikan atau dipasarkan. Penggunaan bahasa yang monoton dan apa adanya akan menimbulkan kesan tidak menarik dan tidak layak jual. Sebaliknya, penggunaan bahasa yang memang dikondisikan untuk menimbulkan kesan mewah akan menarik minat pembeli. Penelitian ini bertujuan untuk mengetahui bagaimana bahasa digunakan untuk menimbulkan kesan baik, mewah, dan berdaya jual tinggi pada iklan perumahan. Pendekatan yang digunakan adalah pendekatan kualitatif, dengan pengumpulan data menggunakan teknik simak dan catat. Data penelitian berupa brosur iklan perumahan yang dikumpulkan selama satu bulan. Hasil penelitian menunjukkan bahwa bahasa menjadi faktor yang sangat penting dalam sebuah komunikasi niaga. Bahasa yang polos dan sederhana akan menimbulkan dampak yang biasa. Akan tetapi, bahasa yang telah dikondisikan akan menimbulkan kesan modern, mewah, berkualitas, dan luar biasa.
\end{abstract}

Kata Kunci: implikatur, wacana, iklan, perumahan 


\section{Pendahuluan}

Bahasa memegang peranan penting dalam kehidupan manusia. Bahasa tidak hanya digunakan sebagai alat untuk mengekspresikan diri dan berkomunikasi dengan orang lain, tetapi juga untuk memengaruhi orang lain. Sejak keberadaannya, manusia sudah selalu berada dalam jagat bahasa. Setiap aktivitas manusia hampir pasti melibatkan bahasa, apa pun bentuknya. Tarigan (2009:4) [1] mengemukakan bahwa bahasa digunakan oleh manusia sebagai sarana komunikasi vital dalam kehidupannya. Pernyataan tersebut mempertegas fungsi utama bahasa, yaitu untuk menyatakan harapan, kritikan, dan opini. Itulah bahasa, yang sengaja atau tidak, selalu hadir mendampingi manusia dalam beraktivitas keseharian, termasuk dalam wacana iklan perumahan.

Sebagai alat komunikasi, bahasa menyampaikan berbagai pesan atau informasi dari orang pertama (penyapa) ke orang kedua (pesapa). Pesan tersebut dapat saja dipahami secara langsung, namun dapat pula dipahami hanya jika didasarkan pada konteks tertentu dalam sebuah komunikasi, misalnya implikatur yang termasuk dalam kajian pragmatik. Wijana (dalam Nadar, 2013: 4) [2] menyebutkan bahwa pragmatik mengkaji makna yang terikat konteks. Makna terbangun bukan hanya dari bentuk ujaran penutur, tetapi juga dari konteks yang melingkupi ujaran tersebut. Hal ini penting, karena penggunaan bahasa dalam kehidupan sehari-hari sering diliputi kesalahpahaman akibat maksud dan informasi dari sebuah ujaran tidak tersampaikan dengan baik.

Menurut Wijana [3], implikatur (implicature) merupakan proposisi (suatu asumsi yang dihasilkan penutur) yang diimplikasikan. Senada dengan Wijana, Oktavianus [4] menjelaskan bahwa implikatur adalah implikasi lain yang dapat diturunkan dari suatu ujaran. Secara sederhana, implikatur dapat dipahami sebagai makna tidak langsung atau makna tersirat yang ditimbulkan oleh yang tersurat. Implikatur dimaksudkan sebagai suatu ujaran yang menyiratkan sesuatu yang berbeda dengan yang diucapkan. Dengan kata lain, menggunakan implikatur dalam percakapan berarti menyatakan sesuatu secara tidak langsung-implikatur adalah maksud, keinginan, atau ungkapan hati yang tersembunyi.

Konsep tentang implikatur pertama kali dikenalkan oleh Grice dalam Oktavianus [5] untuk memecahkan masalah tentang makna bahasa yang tidak dapat diselesaikan dengan teori semantik biasa. Implikatur pun menjadi konsep yang paling penting dalam ilmu pragmatik dan yang menonjolkan pragmatik sebagai suatu cabang ilmu bahasa. Konsep ini dipakai untuk menerangkan perbedaan yang kerap terdapat antara "apa yang diucapkan" dengan "apa yang diimplikasikan." Penggunaan implikatur dalam berbahasa terkait dengan berbagai pertimbangan, seperti untuk memperhalus tuturan, menjaga etika kesopanan, menyindir dengan halus (tak langsung), dan menjaga agar tidak menyinggung perasaan secara langsung.

Implikatur yang terkandung dalam wacana sangat dipengaruhi oleh konteks. Tarigan (1990: 35 dalam Andianto, 200:62)[6] mengartikan konteks ujaran sebagai latar belakang pengetahuan yang diperkirakan dimiliki dan disetujui bersama oleh pembicara (penulis) dan penyimak (pembaca) serta menunjang interpretasi penyimak/pembaca terhadap apa yang dimaksud pembicara/penulis dengan suatu tindak bahasa tertentu. Implikatur yang ditangkap penyimak/pembaca dapat berbeda-beda. Bahasa yang "polos" itu baik, tetapi bahasa yang sudah disesuaikan dengan kebutuhan, itu jauh lebih baik. Penelitian ini mencoba untuk menganalisis penggunaan wacana yang telah "dimodifikasi" agar tujuan yang diharapkan dapat tercapai dengan baik. 


\section{Metode}

Pendekatan yang digunakan dalam penelitian ini menyangkut dua aspek, yaitu aspek teoretis dan metodologis. Secara teoretis, penelitian menggunakan pendekatan pragmalinguistik. Pendekatan pragmalinguistik adalah gabungan analisis pragmatik dan linguistik (struktural). Metode ini melihat wacana berdasarkan statusnya sebagai satuan lingual atau struktur kebahasaan. Akan tetapi, analisis dilakukan dengan mengedepankan aspek-aspek pragmatik (pemakaian bahasa secara langsung). Pendekatan pragmalinguistik dalam penelitian ini digunakan untuk mengkaji bagaimana cara para penutur dan petutur memakai dan memahami tuturan sesuai dengan konteks situasi yang tepat (Wijaya, 1996:2)[7]

Adapun secara metodologis penelitian menggunakan pendekatan kualitatif. Pendekatan kualitatif merupakan prosedur penelitian yang menghasilkan data deskriptif berupa kata-kata tertulis atau lisan dari orang-orang dan perilaku yang diamati (Bagdan dan Taylor dalam Moleong 2002:3)[8]. Pendekatan kualitatif digunakan karena data yang dikumpulkan berupa kata (tuturan), bukan berupa angka-angka. Penelitian ini bertujuan untuk mendeskripsikan implikatur yang digunakan pada wacana iklan perumahan. Data diambil dari flyer atau brosur perumahan di internet mulai dari bulan Agustus sampai Oktober 2020. Dalam kurun waktu tersebut, peneliti mengambil dua puluh wacana untuk diteliti karena data tersebut sudah dianggap mencukupi dan bervariasi. Teknik pengumpulan data dalam penelitian ini adalah teknik simak dan catat. Teknik simak dilakukan dengan menyimak penggunaan bahasa, sementara teknik catat dilakukan dengan menggunakan alat tertentu. Data yang telah didapatkan oleh peneliti dalam bentuk fail lalu dipotong (crop) dan dikumpulkan menjadi satu.

\section{Hasil dan Pembahasan}

Analisis implikatur pada wacana iklan perumahan dilakukan berdasarkan bentuk dan tipe implikatur dalam perspektif pragmatik. Di samping itu, penyampaian bahasa pemasaran akan berimplikasi pada teknik atau cara persuasi atas produk yang akan dijual kepada konsumen. Berikut adalah deskripsi hasil analisis dan pembahasan sesuai dengan analisis implikatur pada wacana iklan perumahan.

Objek dalam penelitian ini adalah iklan perumahan yang berupa brosur dan flyer. Data kajian yang dimaksud berupa nama perumahan dan spesifikasi rumah itu sendiri.
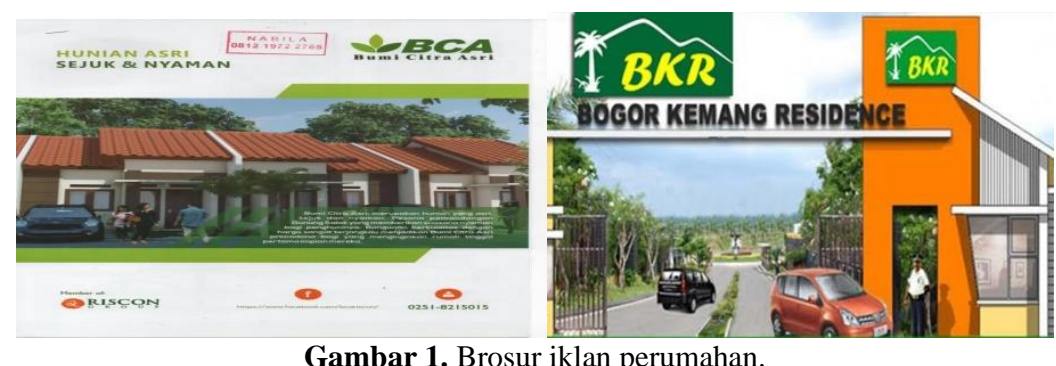

Gambar 1. Brosur iklan perumahan.

Dalam dunia properti, nama-nama perumahan sering menggunakan kata-kata yang memiliki ciri-ciri singkat dan mudah diingat. Sangat disarankan menggunakan nama maksimal empat suku kata. Bila terpaksa, lebih baik gunakan repetisi agar lebih sederhana dan mudah 
diingat atau membuat singkatan hingga jadi ciri khas tersendiri. Contohnya, Bumi Citra Asri disingkat menjadi BCA, Bogor Kemang Residence menjadi BKR, dan lain-lain.

Membangun ciri khas juga dapat dilakukan lewat makna nama. Pemberian nama bisa memberikan makna dan kesan berbeda, bahkan bisa menggambarkan kondisi rumah yang dibeli. Misalnya, nama Bumi Citra Asri atau Bogor Kemang Residence mengesankan bahwa kawasan perumahan tersebut rimbun dengan pepohonan dan ramah lingkungan. Para pengembang perumahan sebisa mungkin membuat nama yang unik dan tidak sama dengan perumahan lain di sekitar lokasi. Hal ini karena nama suatu perumahan akan dipakai dalam jangka waktu lama. Oleh karena itu, mereka berusaha menemukan nama yang tidak termakan waktu.

Nama perumahan Bumi Citra Asri (BCA) dipilih karena memiliki kesan tradisional, memakai kosakata bahasa Indonesia, tetapi tetap menampilkan nuansa kekinian dengan singkatannya BCA. Berbeda halnya dengan nama perumahan Bogor Kemang Residence (BKR). Pemilihan nama perumahan tersebut dilakukan dengan cara mengombinasikan antara nama lokasi perumahan, yaitu Bogor Kemang, dengan kosakata bahasa asing (Inggris), yaitu Residence. Harapannya, agar konsumen lebih tertarik untuk membelinya karena nama tersebut dirasa lebih halus dan sopan. Begitu pun dengan contoh-contoh berikut.

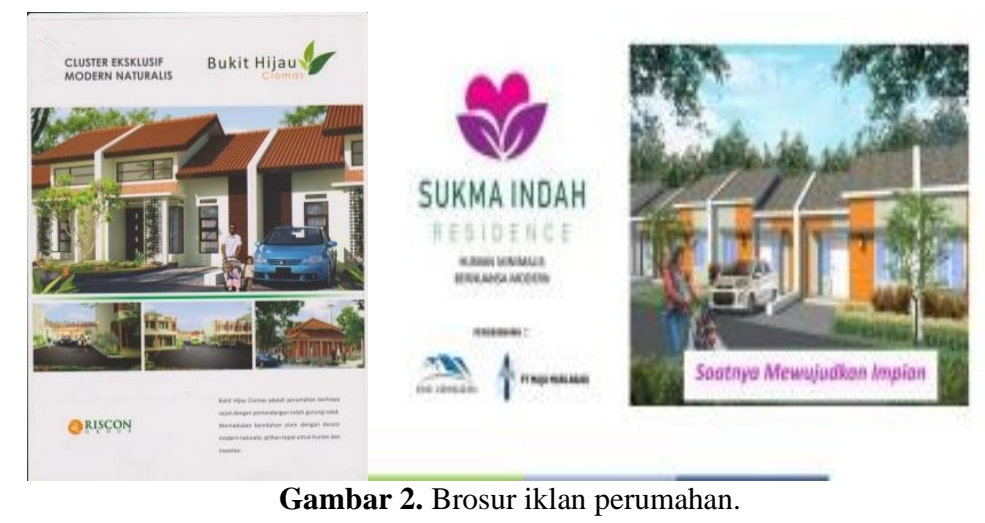

Keunggulan produk dan nama produk merupakan unsur bahasa yang selalu ada pada setiap iklan perumahan. Keunggulan produk jelas harus dikomunikasikan kepada calon konsumen melalui unsur bahasa karena lebih jelas dalam menyampaikan makna dibandingkan unsur nonbahasa. Istilah-istilah tertentu kerap digunakan untuk memasarkan rumah. Tujuannya adalah agar para calon konsumen tertarik untuk membeli rumah. Di antara istilahistilah tersebut adalah "modern naturalis," "hunian asri," "hunian minimalis," "modern," dan lain-lain, yang merupakan karena istilah-istilah yang sudah dikenal di dunia pemasaran rumah. 


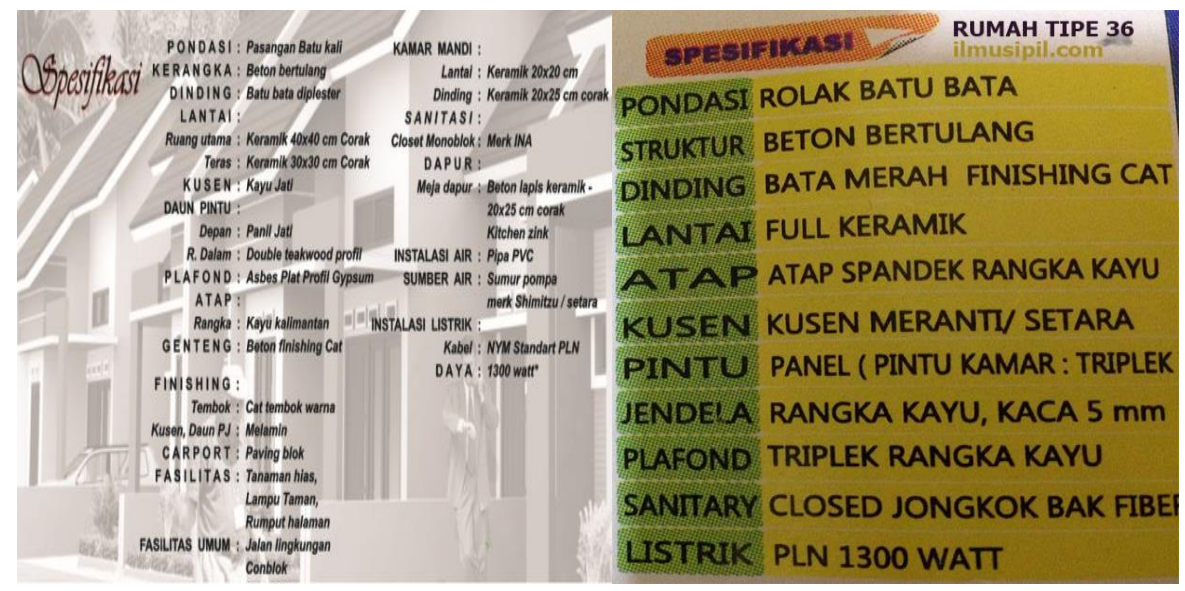

Gambar 3. Spesifikasi perumahan.

Spesifikasi rumah yang tampak dalam dua contoh di atas menampilkan adanya dominasi kosakata bahasa asing (Inggris), seperti "finishing cat," "spandex," "fiber," "double teakwood profile," "kitchen sink," dan lain-lain. Selain itu, terdapat pula beberapa kosakata bahasa Indonesia yang tentunya terkait dengan bidang perumahan, seperti "rolak," "meranti," "panil," "asbes flat profil gypsum," "paving blok," "conblok," "closet monoblok," dan lainlain. Pemilihan kata-kata tersebut tentunya diawali dengan bidang perumahan itu sendiri, sehingga muncullah nama atau istilah tersebut. Pada akhirnya, nama atau istilah pilihan tersebut menimbulkan citra/kesan mewah, halus, dan berdaya jual tinggi daripada jika menggunakan pilihan kata yang apa adanya.

\section{Simpulan}

Implikatur dalam iklan perumahan lebih terfokus pada upaya untuk memperhalus atau menciptakan kesan mewah dengan menggunakan kombinasi bahasa Indonesia, daerah, Inggris, dan kombinasi bahasa/istilah yang lain, padahal bisa jadi kata/istilah tersebut sudah ada padanannya dalam bahasa Indonesia. Upaya ini ditempuh karena bahasa yang telah "dimodifikasi atau dibumbui" lebih menarik minat konsumen daripada bahasa yang tampil dengan apa adanya.

\section{Referensi}

[1] Tarigan, HG. Pengkajian Pragmatik. Bandung. Angkasa; 2009: 4.

[2] Ariani IAPNW, Rasna IW, Wisudariani NMR. Implikatur pada Iklan Layanan Masyarakat. eJournal JPBSI Undiksha. 2016; 4: 12-21.

[3] Wijana, DPI. Dasar-Dasar Pragmatik. Yogyakarta: Andi Yogyakarta. 1996: 27.

[4] Oktvianus. Analisis Wacana, Lintas Bahasa. Padang: Andalas University Press; 2006: 34.

[5] Wijana, DPI. Dasar-Dasar Pragmatik. Yogyakarta : Andi Yogyakarta; 1996: 24.

[6] Moleong LJ. Metode Penelitian Bahasa Tahapan Strategi, Metode, dan tekniknya. Jakarta: PT Raja Grafindo Persada; 2013: 66. 